\title{
Hunger and Angerin the Land: Achieving National Security through Food Security in Nigeria
}

\author{
Ojo-Eyitope Esther Anike \\ Department of Peace and Security Studies, Institute of Peace, Security and Governance. \\ Ekiti State University, Ado Ekiti, Nigeria \\ ojconnect2@yahoo.com
}

\begin{abstract}
It is a common parlance to say that "a hungry man is an angry man". This underscores meetinga basic physiological requirementof all humans, especially food, as an antidote to violence (insecurity) in the society. Like in most sub-Saharan African nations, it is vague to concur that mineral resource dysfunction resulting in advent of the war, conflict and national insecurityare the bane of the agricultural sector and food supplyin Nigeria. This paper therefore attempted to study the nexus between food and security towards a peaceful Nigerian society. Food is proxy by food security in four components and nationalsecurity is proxy by non-military four dimensions and forms.Adopting purposive sampling of secondary data and information from literature, published reports on the variables; analyzed using qualitative content analysis of the textual data, the study revealed that amongst/between individuals and or group, food security being an important nugget, there is existing nexus with national security. It concluded that socioeconomic and political stability (national security) in conflict regions in Nigeria is contingent on supplying a basic human need: food. It recommended that including food security issues in security strategic policy is essential to address national insecurity and instability in Nigeria.
\end{abstract}

Keyword : anger; food; hunger; nigeria; security

\section{Introduction}

Evidently, the world is drifting in diver's directions - economy, education, agriculture, environment, security, etc. More recent concern is vested globallyoninsecurity with its attendant effects on agriculture- practice and food supply chain. There appears glaring nonsustainability, i.e. agriculture defiles adequatefood security to everyone on the planet apparently orchestrated by the several factors i.e. climate change and natural disasters, wars and conflicts, and thesethreaten the future of farming (food production), and fast orchestrating insecurity across, especially in Africa.

Oxfam Novib (2007) reported that Food and Agriculture Organization (FAO) declared about 815 million people in the third world are undernourished, consuming less amount of calories essential for sound health and growth. Agricultural sector which produces and support social and economic life of economies e.g. with food, raw materials, employment, and some other sectors of the economy, is dependent on the natural resources base on the peaceful environment to labor, people's expertise etc. However, apart from climate change risks leading to desertification, mounting temperatures, fluctuating rainfall patterns etc., global conflicts, wars and status of insecurity are emerging threats to food supply and people's welfare especially in the vulnerable sub-Sahara Africa and in Nigeria particularly. Moreover, a neodimensional order to food security is its attendant general insecurity and conflict in that, most food insecure experiencing nations and regions of the world are mostly war and conflict ravagednations and regions of the world especially in Africa(Perez, 2018).A quick example in Africa is Sudan, Eritrea, Somalia, Central African Republic, Niger etc., and inthe sub-regions of Nigeria. 
Nigeria with over 180 million people is the most populous in Africa accounting for $47 \%$ of West Africa's total population (World Bank 2012). However,the political, ethnic and religious risks with the outbreak Boko-Haram and herdsmen debacles concomitantly with war, conflict, food scarcity, poverty etc., are currently leaving over 2 million displaced and malnourished people in the Nigeria Northeast/ west states of Zamfara, Benue, Yobe, Borno and Adamawa in the last 8 years (FGN, 2016; World Bank and National Bureau of Statistics (NBS), 2018). These are dynamic instructivethat puzzled investigative thoughts and necessary to institute informed strategies towards choices of long-term policy decisions for over 7 billion world population, with over 180million share in Nigeria.

This paper therefore attempts to evaluate and access the nexus of the duo of food security and nationalsecurity (insecurity)of life; to drawn attention ofnational strategy and policy switchtowards addressing national insecurity via food security; to suggest coordinated action balance of the duo of food insecurity and national security issues in Nigeria.

\section{Theoretical Review}

Theories of causes of conflict have been categorized using two parameters - the agency and structural parameters. The agency parameter focuses on the psychological and the social, which situate causes of conflict at the level of individual or collective agency and are based on human behavior. This category argue that aggressive behavior is innate, that is, biologically programmed into the human species (Bangura and McCandless, 2007). Some of the most important assumptions of the behaviorist school are that the root causes of war lie in human nature and human behavior; and that there is an important relationship between intrapersonal conflict and conflict that pervades the external social order. The structural parameters analysis is primarily concerned with analyze group interactions at the conscious level (Cunningham, 1998) with the exercise of power - economic, political, military, and cultural- and the use of force - as a process leading to violent conflict- in intergroup relations. It suggests that the assumptions common to the roots of conflict stem from group competition and the pursuit of power and resources.

These approaches is aptly capsulated by the theory of hierarchy of human needs by Abraham Maslow (1954) showcased by the link in the Abraham Maslow`s hierarchy of needs. This states that "different people are at different levels in the need hierarchy inclusive from physiological needs and then progressively move up to self-actualization needs." Hence, as an individual and or group, basic to all humans is the requirement for meeting physiological need of food, water and basic life essential, and subsequent to that is the safety need in terms of protection against violence, threat totally called security in order to enjoy the physiological benefits.

\subsection{Conceptual Review}

Food is not only an important resource, but expected to be essentially and sufficiently available for human existence, survival and development. The term food security is seen as the availability, access, adequacy and safety of consumption in nutritionalproportion to meet the psychological and health requirements of the body of people in the society(Food and Agricultural Organization (FAO) 2014; Etim, Duke and Ogbinyi, 2017).Ojo and Adebayo (2012) economically express food security as a situation in the food system where the food demand side balances the supply side. 
Food security has been declared as a fundamental right i.e. right to adequate food, as established 1948 Universal Declaration of Human Rights (Article 2.1) Specifically, Convention on the Rights of the Child (Article 24.1) in 1989 provides that "Food security is often expressed as when all people, at all times, have physical, social and economic access to sufficient, safe and nutritious food that meets their dietary needs and food preferences for an active and healthy life". To concisely express these fundamentals suggests that equity, availability, accessibility and utilization are prominent. Apparently food security appears a mere concept or hypothetic because the universal does not yet provide adequate food streams or nutrition to everyone in the world- regional, community, household or individual level.

Idachaba, (2004) in contrast, opined that food insecurity exists when the majority of the people in a nation do not have access to food that is adequate in quality and quantity consistent with descent existence at all times. Therefore, paying a cursory look at the food system cycle and structures, (Beddington et al, 2012) asserted that, food system and strategy attracts numerous pressures- population expansion, technology, environmental, social and man-made, land resource exclusion, social inequalitiesetc., - which have made food production and consumption skewed in favourof and a polarization of social groups around powerful, economic and influential (Bartusevicius, 2014). This is evident in the levels of nutrition and diets shift, widespread poverty, food shortage and supplies etc., generally known as food insecurity. Food insecurity contributes to degradation, poverty and illegal depletion of natural resources, rural - urban drift and across borders, and political and economic instability and general insecurity.

National insecurity has attracted such divergent views (Achumba, Ighomereho, and Akpan, 2013; Oladiran, 2014,Matemilola, and Elegbede, 2017) as dearth of protection and uncertainty, lack of safety and confidence, absence of instability and presence of chaos. Insecurity is a breach of peace resulting either from individual or groups capable of upsettingsocio-economic activities in the society. This is evident in cases of ethno-religious strife, political violence, kidnapping, militancy, terrorism etc. In the contrast, national security presupposes an all-inclusive paradigm- social, economic, political and psychological - status and varied pre-conditions which certainlypromote human well-being in the society. Innocent and Onyishi (2014) believe thatnational security is a vital social contract within a sovereign state which allows for perpetual and improved human welfare and well-being in the society. Olaniyan and Omotola (2015) argued that securityhas become a development concern in any modernizing state.

Deducing from these, national security components may therefore be a military-based and non-military dimensions and forms. Military-based traditional perspective of national security possibly accounted for the arms race, military balance of the art technology, military order of battle, military capabilities and strength of nations as effective strategy to deter potential force, aggressors and threats of force to both internal violation and territorial integrity of the state. The non-military dimensions and forms exceed mere war, crime and violence but focus on the physical, socioeconomic and psychological quality of life in the society. It may include economic security, energy security, social security,environmental security, food security, cyber security, infrastructure security etc.

With national security having the focus on people's welfare and well-being, food security being an important nugget, there seem to exist a nexus betweenfood securityand national security especially prevention and protection from violence and crime. It is a common parlance to say that "a hungry man is an angry man". This position explains the subsisting Nigeria 
economy, which though was pivoted on agriculture before and subsequent the political independent in October 1960, (CBN, 2002) contributing about 70\% of the Gross Domestic Product (GDP), employing about the same percentage of the working population, and (CBN, 2000) accounting for about $90 \%$ of foreign earnings and Federal Government revenue. Nigeria being world's largest producer of cassava, cowpea and recently yam, (Nwajiuba, 2012) with an estimated 71 million hectares of cultivable land, Nigeria now ranked a food-deficit nation and depends on imports of grains, livestock and fish products (IFAD 2012). Records show thatonly half of cultivable land is currently used for farming while potential for irrigation stands at only 7 percent of irrigable land.

The result of these has been partly the dilapidating security level across the nation; recent escalation of herds men -famer clashes, boko haram war, increased level of violent crimes, robbery, communal crises, ethno-religious crises, political conflict, unemployment and other social vices amongst youths have been traced to poverty and hunger in the Nigeria (World Bank 2012, Odjugo, 2010).

\subsection{Empirical Review}

Several academic findings diversely allude to the nexus of food security and national security though has been controversial. Respectively, examining empirical literature on this asasserted in the work of (Akwaraet al., 2013) that conflict, violence and insurgency are inform by chronic poverty and inequality - a significant symptom of food insecurity. This scenario engenders more than $80 \%$ of insecurity related issues - deaths- in less economic advantage states. Perez, (2018) found that social ailment like food insecurity does not necessarily inform instability, but that an effective means to successfully ensure security, violence protection and the like is to enable a country to achieve food security on own resources. Succinctly to add that a peaceful and secured world correlates achieving, at least, the 'basic needs' of people are metfood.

A report by (The Economist, 2018), a world renowned magazine, asserted the essential roles ofpolitical stability in agricultural production and relief efforts. The report emphasized that conflict and war are drivers of food insecurity in 18 nations in the world in 2017, evident from damaged infrastructure, displaced populations, destroyed ecosystem and crops, leading to rising food prices. Another report from a Non-Governmental Organization (Fund for Peace, 2017)“Fragile States Index Annual Report" revealed that stabilityand national security in subSaharan Africais crucial and one way toensure this is through provision of basic human needfood.It alluded to Central African Republic (CAR), Somalia and South Sudan with long standing internal conflicts which have undermined the countries food security agenda.

From Nigerian scenario, (Awojobi, 2014) investigated the claim that the high level of poverty in Nigeria has been responsible for the insecurity and found that since the coming of civilian government in 1999, poverty, inequality and unemployment constitute a threat to the Nigeria's national security. This underscores International Fund for Agricultural Development (IFAD) (2012) report that an estimated 70\% of Nigerians are poor, ranked 40th out of 79 on the 2012 Global Hunger Index and avails insecurity vulnerability. Studies by (Ogundele and Jegede, 2011; Oludare, et al., 2012; Odjugo, 2010) were found to reveal interrelationship between adverse ecosystem elements and food insecurity as causality of national insecurity across regions and states in Nigeria. For example, (Odjugo, 2010) study on Overview of Climate Change Impacts in Nigeria revealed varying and hostile effects of climate changeon 
agriculture practice, leading to frequent and seasonal exodus of livestock across the savannah resulting in wanton destruction of farm crops, herders-farmers crisis, life insecurity and food insecurity in Nigeria.

The threats to life and insecurity in Nigeria, in the conclusion of (Jekayinfa and Mofoluwawo, 2010) work is contingent on many causality factors inclusive of the those related to food production, illiteracy and imbalance food supply -population ratio. Growing population pressure and its attendant impacts already diminished resources and further threatening food production through stressed farm land, overgrazing and deforestation. From diversviews, it underscores the facts that allude to the rolefood security in national security.

\section{Research Methodology}

Due to the nature of this research, the most suitable approach adopted is the qualitative research design using comparative summative content analysis method. This was achieved through purposive sampling of secondary data and information from literature, published reports etc., based on research variables- national security and food security.The qualitative content analysis of literary content sources is one of numerous research methods used to analyze text data, focusing on the de-contextualization, re-contextualization, categorization and compilation of related characteristics of language as communicated with attention to the content or contextual meaning of the text (Tesch, 1990; Bengtsson, 2016). Hence, this work adopted (Bengtsson, 2016) suggested analysis schedule with slight modification, involvingmeaning unit of textual data, comparing and codification oftextual data, categorization of the text into main and sub themes (with source reference/citation) with the aim to develop possible relationship between research variables and to elicit a finding. The work was then presented in purposively stratifiedtabular format.

Table 1. An analysis schedule of Textual Data from Literature on Food Security.

\begin{tabular}{|l|l|l|}
\hline Meaning Unit & Food Security & Main Theme \\
\hline $\begin{array}{l}\text { "Food security relies on the capacity of } \\
\text { interconnected social, economic and biophysical } \\
\text { systems to meet people's nutritional } \\
\text { requirements". }\end{array}$ & Category & Reference \\
\hline $\begin{array}{l}\text { "food security is an access by all people at all } \\
\text { times to enough food for an active healthy life at } \\
\text { present plus the ability to provide enough for } \\
\text { future generation" }\end{array}$ & Food Availability & $\begin{array}{l}\text { Metu A. G., Okeyika O. } \\
\text { K and D. M. Olisa } \\
\text { (2016). }\end{array}$ \\
\hline $\begin{array}{l}\text { food security " exists when all people, at all } \\
\text { times, have physical and economic access to } \\
\text { sufficient, safe and nutritious food that meets } \\
\text { their dietary needs and food preferences for an } \\
\text { active and healthy life }\end{array}$ & Food Equity & $\begin{array}{l}\text { The World Food } \\
\text { Summit, 1996, }\end{array}$ \\
\hline $\begin{array}{l}\text { "...Is determine by food quality, nutritional } \\
\text { values, preparation method and storage as well } \\
\text { as feeding pattern. }\end{array}$ & Food Utilization & $\begin{array}{l}\text { Matemilola, S. and } \\
\text { Elegbede, I. (2017). }\end{array}$ \\
\hline
\end{tabular}


Food insecurity has been seen from the area of limited access to nutritionally adequate and safe foods due to lack of resources

Table 2. Analysis schedule of Textual Data from Literature on National Security

\begin{tabular}{|c|c|c|}
\hline & National Security & Main Theme \\
\hline Meaning Unit & Code Names & Reference \\
\hline $\begin{array}{l}\text { Security means protection from hidden and hurtful } \\
\text { disruptions in the patterns of daily life in homes, } \\
\text { offices or communities. Security may also be defined } \\
\text { as the state of being or making safe secure from } \\
\text { danger, etc }\end{array}$ & Physical security & $\begin{array}{l}\text { Otto G. and Ukpere W. I. } \\
\text { (2012) }\end{array}$ \\
\hline $\begin{array}{l}\text { "Every person has a right to life, and no one shall be } \\
\text { deprived intentionally of his life, save in execution of } \\
\text { the sentence of a court in respect of a criminal } \\
\text { offence of which he has been found guilty in Nigeria." }\end{array}$ & Security of Life & $\begin{array}{l}\text { Nigerian Constitution } \\
\text { (1999) section 33(1) and } \\
\text { (4). }\end{array}$ \\
\hline $\begin{array}{l}\text { "Security can be said to be the protection of values } \\
\text {......provide and protect most cherished values and } \\
\text { beliefs, way of life....." }\end{array}$ & Social Security & $\begin{array}{l}\text { Innocent E.C. and Onyishi } \\
\text { T.O. (2014). }\end{array}$ \\
\hline $\begin{array}{l}\text { "National security focus on the physical, social and } \\
\text { psychological quality of life of a society ....the } \\
\text { tranquility and well-being of a society are pre- } \\
\text { conditions for security" }\end{array}$ & Economic Security & Yibaikwal S. (1988). \\
\hline $\begin{array}{l}\text { "..traditional notion of national security places } \\
\text { emphasis on the protection of state's sovereignty and } \\
\text { territorial integrity against domestic and external } \\
\text { threats." }\end{array}$ & Territorial Security & $\begin{array}{l}\text { Thomas A.N. and Aghedo } \\
\text { I.(2014). }\end{array}$ \\
\hline
\end{tabular}

Source: Author, 2019

Table 3. An analysis schedule of Textual Data from Literature on National Security and Food Security.

\begin{tabular}{|c|c|c|c|c|}
\hline & $\begin{array}{c}\text { National } \\
\text { Security; } \\
\text { Food Security }\end{array}$ & $\begin{array}{l}\text { National } \\
\text { Security }\end{array}$ & $\begin{array}{c}\text { Food } \\
\text { Security }\end{array}$ & $\begin{array}{c}\text { Main } \\
\text { Theme }\end{array}$ \\
\hline Meaning Unit & $\begin{array}{c}\text { Condensed } \\
\text { Meaning Unit }\end{array}$ & Category & Category & Reference \\
\hline $\begin{array}{l}\text { "...rustling and banditry activities have } \\
\text { been a veritable threat to public safety } \\
\text { and security ...."multidimensional nature } \\
\text { of human security is underlined by the } \\
\text { recognition given to economic, food, } \\
\text { health, environmental, personal, } \\
\text { community...." }\end{array}$ & $\begin{array}{l}\text { Violence, } \\
\text { Stealing and } \\
\text { Arson lead to } \\
\text { low food } \\
\text { production and } \\
\text { goods/services }\end{array}$ & $\begin{array}{l}\text { Physical and } \\
\text { economic } \\
\text { security }\end{array}$ & $\begin{array}{l}\text { Food } \\
\text { Accessibility }\end{array}$ & $\begin{array}{l}\text { Shehu, S.A., } \\
\text { Victor } \\
\text {.E,andBinta M. } \\
\text { (2017) and } \\
\text { Egwu S. (2016) }\end{array}$ \\
\hline $\begin{array}{l}\text { " Being deprived from what a person } \\
\text { believes he is entitled to, ....food security } \\
\text { and improved standard of living, ...could } \\
\text { lead to violence or threat of violence." }\end{array}$ & $\begin{array}{l}\text { Socioeconomic } \\
\text { injustice } \\
\text { promotes } \\
\text { aggression and } \\
\text { poverty }\end{array}$ & Social Security & Food Availability, & Etim et al. 2017 \\
\hline $\begin{array}{l}\text { "Given that the conflict is related to } \\
\text { access to arable land, ... food insecurity } \\
\text { situation ...the North East and South } \\
\text { South, food insecure households have }\end{array}$ & $\begin{array}{l}\text { Criminal actions } \\
\text { and concerns } \\
\text { impair on basic } \\
\text { needs across }\end{array}$ & $\begin{array}{l}\text { Territorial and } \\
\text { economic } \\
\text { security }\end{array}$ & $\begin{array}{l}\text { Food Equity and } \\
\text { availability }\end{array}$ & $\begin{array}{l}\text { Mercy Corps } \\
(2015) \text { : } \\
\text { National Bureau } \\
\text { of Statistics, } \\
\text { NBS (2017): }\end{array}$ \\
\hline
\end{tabular}




\begin{tabular}{|c|c|c|c|c|}
\hline $\begin{array}{l}\text { been slightly more affected by conflict } \\
\text {..." }\end{array}$ & $\begin{array}{l}\text { regional } \\
\text { locations }\end{array}$ & & & \\
\hline $\begin{array}{l}\text {..... security challenges facing Nigeria } \\
\text {....have their root causes in the high level } \\
\text { of inequality .... conflict post- } \\
\text { independence ...interrupted production of } \\
\text { food and displaced people leaving fertile } \\
\text { land uncultivated" }\end{array}$ & $\begin{array}{l}\text { Bigotry explains } \\
\text { interrupted } \\
\text { supplies of } \\
\text { elements of } \\
\text { welfare }\end{array}$ & Social Security & $\begin{array}{l}\text { Food Utilization } \\
\text { and Sufficiency }\end{array}$ & $\begin{array}{l}\text { Akwara et al. } \\
(2013), \\
\text { Adeagbo, M.O. } \\
(2012)\end{array}$ \\
\hline $\begin{array}{l}\text { "ethnic..... crises have had negative } \\
\text { implications for the security of the } \\
\text { country....... worse still, many more have } \\
\text { been displaced or become refugees, } \\
\text { developments that further compound the } \\
\text { welfare of the people }\end{array}$ & $\begin{array}{l}\text { Communal feud } \\
\text { inimical to } \\
\text { overall } \\
\text { development } \\
\text { and welfare }\end{array}$ & $\begin{array}{l}\text { Territorial and } \\
\text { social security }\end{array}$ & $\begin{array}{l}\text { Food Sufficiency, } \\
\text { Accessibility and } \\
\text { Availability, }\end{array}$ & $\begin{array}{l}\text { Olaniyan A. and } \\
\text { Omotola } \\
\text { S.(2015): }\end{array}$ \\
\hline $\begin{array}{l}\text { " However, the most effective means of } \\
\text { improving security, community based } \\
\text { violence protection, and successfully } \\
\text { implemented transition planning is to } \\
\text { enable a country to achieve food security } \\
\text { through its own resources }\end{array}$ & $\begin{array}{l}\text { Improving } \\
\text { security and } \\
\text { violence } \\
\text { involves } \\
\text { providing food } \\
\text { resources }\end{array}$ & $\begin{array}{l}\text { Economic } \\
\text { security }\end{array}$ & $\begin{array}{l}\text { Food } \\
\text { Accessibility }\end{array}$ & $\begin{array}{l}\text { Adebakin M.A. } \\
\text { (2012). }\end{array}$ \\
\hline $\begin{array}{l}\text { "These security threats appear to have } \\
\text { adversely impacted on the Nigerian } \\
\text { economy, the image of the country in the } \\
\text { global arena and social relations among } \\
\text { the Nigerian citizens". }\end{array}$ & $\begin{array}{l}\text { Security threats } \\
\text { adversely } \\
\text { impacted on the } \\
\text { Nigerian } \\
\text { economy } \\
\text { sectors }\end{array}$ & $\begin{array}{l}\text { Social and } \\
\text { economic } \\
\text { security }\end{array}$ & Food Availability, & $\begin{array}{l}\text { Nwagboso } \\
\text { C.I.(2016). }\end{array}$ \\
\hline
\end{tabular}

Source: Author, 2019

\section{Discussion}

Table 1, succinctly attempted to categorized food security into five (5) issues of availability, access, adequacy, equity and sufficiency. This underscores Food and Agricultural Organization (FAO) concept of psychological and health requirements of food forthe body in the society. Many plans, policies and programmes, globally and nationally in Nigeria, had and subsist in accommodating food security as top target or goal. Millennium Development Goals (MDGs)(1990-2015), National Accelerated Food Production Project (NAFPP) (1974), Special Program for Food Security (SPFS)(2004), Anchor Borrower for Rice Production(2016), Bank for Agriculture just to mention a few. Yet, one of the greatest challenges in Nigeria remainedfood availability, access, adequacy, equity and sufficiency with the effects of poverty, hunger, anger, violence and conflict in the rural regions of Nigeria (Food Security Portal, 2014).

From Table 2,sufficiently stratified national security in components, dimensions and forms concerned with development issues and not solely of a military-based perspectivein a modernizing society. Physicalmilitary-based security and non-military variables are all and both imperative and conjointly reinforcingnational security(World Bank Report, 2001) as "the overall goal of development as the totality of welfare and enhancement of the qualitative existence of the populace through increasing economic, political and civil rights of the people without discrimination across gender, ethnicities, religions, races, regions and countries".

In Table 3, the duo of the variables of national security and food security has connection and that attaining national security is contingent on food security. For example, kidnapping is motivated by economic factors and that common reason behind kidnapping across Nigeria is 
the rising incidence of chronic poverty and unemployment amongst youth, mostly in the midst of abundant natural resources.

Again, where food is available not sufficiently distributed, a poor hungry man will remain food insecure and become vulnerable to conflict as a survival strategy. This position (Perez, 2017) forms core of United States of America national security strategy for vulnerable Africa states through humanitarian element and response. For example, US Congress addressed the crisis in Central Africa Republic, Sudan and Somalia via food support as a major prong of its social and economic security stabilization strategy.

A strong economic security is guaranteed by food affordabilityand utilizationin other sector e.g. production sector thereby generating human service engage and innovation and hence national security. Terrorist organizations and conflict thrive in environments where agricultural growth is deterred to create investment, and the problem compound the people to be weak. Low food prices through increase agricultural practices and supply encourages social networking, organized cooperation, and general physical security.

\section{Conclusion}

Food appears now an imperative weapon in development issue, international diplomacy and global security. It is an instrument of national power and security. Any deprivation of basic necessities of life such as food security informs grave consequences on the global and local communities. From these views, it concluded thatnational security in conflict regions in Nigeria is contingent on the availability, utilization and sufficiency of a basic human need: food as a strategy for socioeconomic and political stability of Nigeria.

\section{References}

Adeagbo, M.O. (2012) Curbing the Menace of Food Insecurity in Nigeria's Democratic Setting. International Journal of Economic Development Research and Investment. 5(6)101-109

Adebakin M.A. (2012). National security challenges and sustainable economic development:

Evidence from Nigeria. Journal of Studies in Social Sciences;1(1):1-30.

Achumba I.C, Ighomereho O.S, and AkpanRobaro M.O.M.(2013). Security challenges in Nigeria and the Implications for Business Activities and Sustainable Development. Journal of Economics and Sustainable Development.;4(2):79-99.

Akwara, A. F., Awara, N. F., Enwuchoia, J., Adekunle, M. and Udaw, J. E. (2013).

Unemployment and Poverty: Implication for National Security and Good Governance in

Nigeria. International Journal of Public Administration (IJPAMR), October, 2(1)45-57

Awojobi O. N.(2014). Poverty and Insecurity in Nigerian Democratic Dispensation.

International Journal Of Innovative Research \&Development.June.3(6)357-365

Bangura, A. K., andMcCandless, E. (2007). The State of Peace and Conflict Studies and

Peace-building and Development. In E. McCandless, A. K. Bangura, M. E. King, \& E. Sall

(Eds.), Peace Research for Africa: Critical Essays on Methodology (pp. 29-54). Addis

Ababa: University for Peace Africa Programme.

Bartusevic `ius, H. (2014). "The Inequality-Conflict Nexus Re-examined: Income, Education and Popular Rebellions.” Journal of Peace Research 51 (1): 35-50. 
Beddington J, Asaduzzaman M, Clark M, Fernández A, Guillou M, Jahn M, Erda L, Mamo T, Van Bo N, Nobre CA, Scholes R, Sharma R, Wakhungu J. (2012). Achieving food security in the face of climate change: Final report from the Commission on Sustainable Agriculture and Climate Change.CGIAR Research Program on Climate Change, Agriculture and Food Security (CCAFS). Copenhagen, Denmark. Available online at: www.ccafs.cgiar.org/commission.

Bengtsson (2016).How to Plan and Perform Qualitative Research Using Content Analysis.M. Nursing Plus Open2, Elsevier, 8-14

Central Bank of Nigeria (CBN) (2000). Changing Structure of the Nigerian Economy. Central Bank of Nigeria (CBN) (2002). Annual Report and Statement of Accounts.

Egwu S. (2016). The Political Economy Of Rural Banditry In Contemporary Nigeria, in Rural Banditry And Conflicts In Northern Nigeria edited by Mohammed J. Kuna and Jibrin Ibrahim. Centre For Democracy And Development,Abuja. 13-67

Etim E. E., Duke O. O. And OgbinyiJ. O.(2017). The Implications of Food Insecurity,

Poverty and Hunger on Nigeria's National Security .Asian Research Journal of Arts and Social Sciences. 4(2): 1-10

Food and Agriculture Organization (FAO) (1996). Rome Declaration on World Food Security and World Food Summit Plan of Action.

http://www.fao.org/docrep/003/w3613e/w3613e00.HTM

Foodand Agriculture Organization (FAO) 2011. The state of the food insecurity in the world: how does international price volatility affect domestic economies and food security? Rome: Food and agriculture organization of the United. Available online at: www.ccafs.cgiar.org/commission.

Food Security Portal (2014).Food Security Portal-Nigeria.http://www.foodsecurityportal.org/nigeria Fund for Peace (2017): Fragile States Index Annual Report 2017, No 7.

Idachaba, F.S (2004) Food Security in Nigeria: Challenges under democratic Dispensation. Lecture delivered at ARMTI (9th Lecture Series). 25th March 2004.

Innocent E.C. and Onyishi T.O. (2014).Boko Haram and security challenges in Nigeria. Kuwait Chapter of Arabian Journal of Business and Management Review.3(11).

Jekayinfa A.A, and Mofoluwawo E. O.(2010). Problems of food and national security in

Nigeria: Challenges for Social Science Education. Nigerian Journal of Social Studies.; 12:316325.

Jerome, A. (2012). Nigeria's Food Security Programs: Implications for MDG's Goal of Extreme Hunger Eradication. International Journal of Business and Social Science, 3, 243-253. Matemilola, S. and Elegbede, I. (2017).The Challenges of Food Security in Nigeria. Open Access Library Journal , 4: e4185. https://doi.org/10.4236/oalib.1104185

Mercy Corps (2015): The Economic Costs of Conflict Evidence on violence, livelihoods, and resilience in Nigeria's Middle Belt

Metu A. G., Okeyika O. K and D. M.Olisa(2016). Achieving Sustainable Food Security in Nigeria: Challenges and Way Forward. $3^{\text {rd }}$ International Conference on African Development Issues.Convenant University Press. Pg. 182-187

National Bureau of Statistics, NBS (2017): Labour Productivity Report Q4 2016, June 2017. http://nigerianstat.gov.ng/elibrary

Newton M N, Jukka K. and John S. (2010). Impacts of agricultural trade and market liberalization of food security in developing countries: comparative study of Kenya and Zambia. Contributed Paper presented at the Joint 3rd African Association of Agricultural 
Economists (AAAE) and 48th Agricultural Economists Association of South Africa (AEASA) Conference, Cape Town, South Africa, September 19-23.

Nigerian Constitution (1999) section 33(1) and (4). Nwagboso C.I.(2016). The Nature of Internal Security Problems in African States: The Nigerian Experience.International Journal of Academic Research in Business and Social Sciences. April 6(4)38-71

Nwajiuba, C. (2012). Does agriculture have a future in southeast Nigeria? Inaugural lecture, No. 5. Imo State University Owerri, Nigeria.

Odjugo, P. A. (2010). General Overview of Climate Change Impacts in Nigeria. J Hum Ecol, 29(1): 47-55.

Olaniyan A.and Omotola S.(2015).Ethnic crises and national security in Nigeria. Defense And Security Analysis. 1-16, http://dx.doi.org/10.1080/14751798.2015.1087104

Oludare, H, A., Bashir, O, O., and Olusegun, H, A,. (2012).Building capabilities for flood disaster and hazard preparedness and risk reduction in Nigeria: need for spatial planning and land management. Journal of Sustainable Development in Africa .14(1))24-39

Ogundele, J. A. and Jegede, A. O. (2011) Journal of Environmental Issues and Agriculture in Developing Countries, Vol. 3, No. 2 , 72-79

Oladiran A. (2014). Security challenge and development in Nigeria: Leadership to therescue? International Journal of Academic Research in Public Policy and Governance.January.1

Ojo E. O and Adebayo F. P. (2012).Food security in Nigeria: An overview. European Journal of Sustainable Development.1(2)

Otaha, I.J. (2013) Food Insecurity in Nigeria: Way Forward. An International MultidisciplinaryJournal. 7, 26-35.

Otto G. and Ukpere W. I. (2012).National security and development in Nigeria. AfricanJournal of Business Management.June, 6 (23), 6,765-6,770

Perez A.(2018). "Food Security as U.S. National Security: Why Fragile States in Africa Matter,"Pepperdine Policy Review: Vol. 10 , Article 8.

Shehu, S.A., Victor .E,andBinta M. (2017). The menace of cattle rustling and banditry in North-west Nigeria: A Case Study of Katsina state. IOSR Journal of Research and Method in Education (IOSR-JRME) ,7(6) 40-47

Tesch, R. (1990). Qualitative research: Analysis types and software tools. Bristol, PA: Falmer.The Economist (2018). Global Food Security Index 2018 Building resilience in the face of Rising food-security risks. Pg. 1-49

Thomas A.N. and AghedoI 2014). Security Architecture and Insecurity Management: Context, Content and Challenges In Nigeria. Sokoto Journal of the Social Sciences.June, 4(1)2236

Yibaikwal S. (1988). The concept of national security re-visited. Nigerian Forum. Nigerian Institute of International Affairs. Lagos. November- December, 282-292.

World Bank Report (2001). Conflict, Security and Development, http://siteresources.worldbank.org(accessed March 5, 2019).

World Bank and National Bureau of Statistics,(2018). Food Insecurity in Conflict Affected Regions in Nigeria: Results from the North East, North Central, and South Southzones. Preliminary Draft Report. 